ISSN: $1858-4837$

E-ISSN: 2598-019X

Volume 14, Nomor 1 (2019),

https://jurnal.uns.ac.id/region

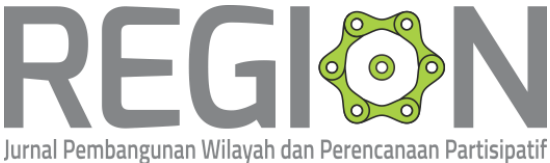

\title{
Faktor-faktor yang Mempengaruhi Pemilihan Moda Bermotor Anak dalam Mengakses Sekolah Dasar di Kota Surakarta
}

\section{The Factors Influencing of Children Selection Motorized in Accessing Primary School in Surakarta}

\author{
Salsabila Imtiyas a, Rufia Andisetyana P b, Erma Fitria Rini c \\ a Prodi Perencanaan Wilayah dan Kota, Fakultas Teknik, Universitas Sebelas Maret \\ ${ }^{b}$ Prodi Perencanaan Wilayah dan Kota, Fakultas Teknik, Universitas Sebelas Maret \\ ${ }^{c}$ Prodi Perencanaan Wilayah dan Kota, Fakultas Teknik, Universitas Sebelas Maret \\ Email: imtiyassalsabila@gmail.com
}

\begin{abstract}
Abstrak
Pada bulan Juli 2017, Kota Surakarta ditetapkan sebagai Surakarta Kota Layak Anak untuk kategori Utama. Kota Surakarta sebagai kota layak anak harus memenuhi kebutuhan layak anak hingga pada skala lingkungan (neighbourhood unit). Salah satu fasilitas sosial dasar untuk anak yang penting dan harus tersedia di neighbourhood unit adalah sekolah dasar. Meskipun terdapat ketersediaan fasilitas sekolah dasar di dalam neighbourhood unit dan keterpenuhan kriteria kota layak anak, namun masih adanya masyarakat yang memilih menggunakan kendaraan bermotor untuk mengakses sekolah dasar setiap hari yang mengakibatkan adanya emisi gas buang. Hal tersebut sebenarnya bisa diminimalisir dengan kemampuan berjalan kaki anak dalam mengakses sekolah dasar. Penelitian ini menjelaskan mengenai faktor-faktor yang mempengaruhi pemilihan moda bermotor anak dalam mengakses sekolah dasar di Kota Surakarta. Penelitian ini menggunakan data primer berupa penyebaran kuisioner kepada 138 responden.Teknik yang digunakan dalam penelitian ini adalah teknik analisis faktor.Berdasarkan pembahasan dan analisis dalam penelitian ini dapat disimpulkan bahwa melalui analisis faktor dapat diperoleh 6 kelompok faktor yang mempengaruhi pemilihan moda bermotor anak dalam mengakses sekolah dasar di Kota Surakarta. Kelompok faktor pertama memiliki pengaruh paling besar dalam mempengaruhi pemilihan moda bermotor anak dalam mengakses sekolah dasar di Kota Surakarta dengan nilai sebesar 33,927\%.
\end{abstract}

Keywords: Faktor Pemilihan Moda Bermotor Anak, Kota Layak Anak, Surakarta Layak Anak, Sekolah Dasar.

\begin{abstract}
In July 2017, Surakarta City was designated as Surakarta Kota Eligible Child for Main category. Surakarta city as a child-worthy city must meet the children's decent needs to the neighborhood scale (neighborhood school). One of the basic social facilities for children that is important and should be available in the neighborhood unit is elementary school. Despite the availability of primary school facilities within the neighborhood unit and the fulfillment of criteria for city-worthy children, there are still people who choose to use motor vehicles to access primary schools every day resulting in exhaust emissions. This can actually be minimized with the ability to walk the child in accessing primary school. This study explains the factors that influence the selection of motorized children in accessing primary school in Surakarta. This study uses primary data in the form of questionnaires distributed to 138 respondents. Technic used in this
\end{abstract}


Region, Vol. 14, No.1, Januari 2019: 13-36

research is factor analysis techniques.Based on the discussion and analysis in this study can be concluded that through the factor analysis can be obtained 6 groups of factors that influence the selection of motorized children in accessing schools base in Surakarta City. The first factor group had the most influence in influencing the selection of motorized children in accessing primary school in Surakarta City with a value of $33.927 \%$.

Keywords: Faktor Pemilihan Moda Bermotor Anak, Kota Layak Anak, Surakarta Layak Anak, Primary School.

\section{PENDAHULUAN}

Anak merupakan masa depan dan generasi penerus cita-cita bangsa, negara berkewajiban memenuhi hak setiap anak atas kelangsungan hidup, tumbuh dan berkembang, berpartisipasi serta mendapatkan perlindungan dari tindak kekerasan dan diskriminasi (Kementerian Pemberdayaan Perempuan dan Perlindungan Anak, 2015). Salah satu bentuk upaya pemerintah dalam memberikan perlindungan anak diwujudkan dalam Kota Layak Anak. Kota Layak Anak merupakan kota yang mempunyai sistem pembangunan berbasis hak anak melalui pengintegrasian komitmen dan sumber daya pemerintah, masyarakat dan dunia usaha, yang terencana secara menyeluruh dan berkelanjutan dalam kebijakan, program dan kegiatan untuk menjamin terpenuhinya hak dan perlindungan anak (Kementerian Pemberdayaan Perempuan dan Perlindungan Anak, 2015). Tujuan adanya Kota Layak Anak adalah untuk meningkatkan komitmen dalam bentuk kebijakan, program dan kegiatan pembangunan yang ditujukan untuk pemenuhan hak dan perlindungan anak. Berdasarkan Peraturan Menteri Pemberdayaan Perempuan dan Perlindungan Anak Nomor 12 Tahun 2011 yang mengatur tentang 31 (tiga puluh satu) indikator ketercapaian penerapan Kota Layak Anak (KLA), salah satunya yaitu ketersediaan fasilitas sosial yang mengakomodasi hak-hak anak.

Kota dan bagian-bagian kota didalamnya merupakan suatu organisme yang berkaitan satu sama lain, sehingga setiap perkembangan pada unit lingkungan terkecil (neighbourhood unit) sekalipun mempunyai kaitan dengan perkembangan kota secara menyeluruh (Sujarto, 1976 dalam Putri, 2012). Penerapan Kota Layak Anak dalam penyediaan fasilitas sosial seharusnya tidak hanya diterapkan dalam skala kota namun juga pada skala unit lingkungan hunian terkecil atau neighbourhood unit. Selain itu, usia anak memiliki keterbatasan pergerakan mandiri dibandingkan manusia dewasa sehingga ketersediaan fasilitas sosial layak anak pada skala neighbourhood unit merupakan kriteria penting dalam mewujudkan kota layak anak (Rini, et al., 2017). Pada bulan Juli 2017, Kota Surakarta ditetapkan sebagai Surakarta Kota Layak Anak untuk kategori Utama. Kota Surakarta sebagai kota layak anak harus memenuhi kebutuhan layak anak hingga pada skala 
Salsabila Imtiyas dkk, Faktor-faktor yang...

lingkungan (neighbourhood unit). Berdasarkan penelitian Rini, et al., (2017), Kota Surakarta terbagi menjadi 109 neighbourhood unit berdasarkan kriteria:

1. Jangkauan pelayanan SD sebesar 800 meter

2. Batas administrasi lingkungan yaitu RT dan RW

3. Batas fisik berupa jalan \& sungai.

Salah satu fasilitas sosial dasar untuk anak yang penting dan harus tersedia di neighbourhood unit adalah sekolah dasar. Hal tersebut dikarenakan sekolah dasar merupakan fasilitas sosial yang wajib ditempuh usia anak dengan frekuensi penggunaan harian. Pada konsep ideal The neighbourhood unit, sekolah dasar merupakan pusat unit lingkungan hunian dan kemampuan jarak tempuh berjalan kaki usia anak menjadi dasar penentuan besaran neighbourhood unit (Perry, 1929 dalam Rini, et, al., 2017). Jika fasilitas sekolah dasar tidak tersedia pada skala neighbourhood unit maka akan terjadi pergerakan moda transportasi berupa kendaraan bermotor yang seharusnya bisa diminimalisir dengan kemampuan berjalan kaki anak dalam mengakses sekolah dasar dalam lingkup skala neighbourhood unit. Adanya pergerakan kendaraan bermotor yang dilakukan setiap hari menuju ke sekolah menyebabkan emisi gas buang seperti CO2 (karbon dioksida), CO (karbon monoksida), HC (hidrokarbon), NOx (nitrogen oksida), SOx (sulfur oksida), PB (timbal), dan partikulat sehingga menyebabkan terjadinya perubahan iklim (Wahyu dalam Indra, 2013).

Kota Surakarta memiliki 263 sekolah dasar/sederajat dengan jenis sekolah dasar negeri, sekolah dasar swasta, Madrasah Ibtidaiyah (MI) serta sekolah bagi siswa berkebutuhan khusus (SLB) (Dinas Pendidikan Kota Surakarta, 2017). Dari total jumlah siswa sekolah dasar di Kota Surakarta didapatkan sebesar 52,87\% siswa bersekolah di dalam neighbourhood unit, dengan jumlah siswa yang menggunakan kendaraan bermotor sebagai moda yang digunakan untuk menuju ke sekolah dasar dan sederajat di Kota Surakarta yaitu sebesar 60,38\% (Rini, et, al., 2017). Meskipun terdapat ketersediaan fasilitas sekolah dasar di dalam neighbourhood unit dan keterpenuhan kriteria kota layak anak, namun masih adanya masyarakat yang memilih menggunakan kendaraan bermotor untuk mengakses sekolah dasar setiap hari yang mengakibatkan adanya emisi gas buang. Hal tersebut sebenarnya bisa diminimalisir dengan kemampuan berjalan kaki anak dalam mengakses sekolah dasar. Oleh karena itu dalam penelitian ini penulis ingin mengetahui faktor-faktor yang mempengaruhi pemilihan moda bermotor anak dalam mengakses sekolah dasar di Kota Surakarta. 


\section{TINJAUAN TEORI}

\subsection{Karakter Anak Usia Sekolah Dasar}

Alfajar (2014) menjelaskan bahwa usia anak SD dapat dikatakan bahwa anak memasuki perkembangan masa kanak-kanak akhir dimana masa ini dialami oleh anak yang berusia 6 sampai 11-13 tahun. Anak SD merupakan anak dengan katagori banyak mengalami perubahan yang sangat drastis baik mental maupun fisik.

a. Perkembangan Bahasa

Pada masa ini perkembangan bahasa nampak pada perubahan perbendaharaan kata dan tata bahasa. Bersamaan dengan masa sekolah, anak-anak semakin banyak menggunakan kata kerja seperti memukul, melempar, menendang dan menampar.

b. Perkembangan Moral

Perkembangan moral ditandai dengan kemampuan anak untuk memahami aturan, norma dan etika yang berlaku di masyarakat. Perilaku moral banyak dipengaruhi oleh pola asuh orang tuanya serta perilaku moral dari orangorang disekitarnya.

c. Perkembangan Emosi

Emosi melakukan peran yang penting dalam kehidupan anak. Akibat dari emosi ini juga dirasakan oleh fisik anak terutama bila emosi itu kuat dan berulang-ulang. Pergaulan yang semakin luas membawa anak belajar bahwa ungkapan emosi yang kurang baik tidak diterima oleh temantemanya. Anak belajar mengendalikan ungkapan-ungkapan emosi yang kurang dapat diterima seperti: amarah, menyakiti perasaan teman, ketakutan dan sebagainya

d. Perkembangan Sosial

Perkembangan emosi pada masa anak-anak akhir tak bisa dipisahkan dengan perkembangan sosial, yang sering disebut dengan perkembangan tingkah laku sosial. Orang-orang di sekitarnyalah yang banyak mempengaruhi perilaku sosialnya. Dunia sosioemosional anak menjadi semakin kompleks dan berbeda dengan masa ini. Interaksi dengan keluarga, teman sebaya, sekolah dan hubungan dengan guru memiliki peran penting dalam hidup anak. Pemahaman tentang diri dan dan perubahan dalam perkembangan gender dan moral menandai perkembangan anak selama masa kanak-kanak akhir. Bermain secara berkelompok memberikan peluang dan pelajaran kepada anak untuk berinteraksi, bertenggang rasa dengan sesama teman. Permainan yang 
Salsabila Imtiyas dkk, Faktor-faktor yang...

disukai cenderung bermain berkelompok. Pengaruh teman sebaya sangat besar baik yang bersifat positif seperti pengembangan konsep diri dan pembentukan harga diri, maupun negatif.

\subsection{Faktor-faktor yang Mempengaruhi Pengambilan Keputusan}

Kotler (2003) menjelaskan bahwa faktor-faktor yang mempengaruhi pengambilan keputusan adalah faktor budaya yang merupakan penentu keinginan dan perilaku dasar manusia. Setiap manusia mendapat seperangkat nilai dan preferensi dari keluarga dan lembaga-lembaga penting lainnya. Semua kehidupan bermasyarakat selalu memiliki kelas sosial. Orang-orang dalam kelas sosial yang sama cenderung berperilaku lebih seragam daripada orang-orang dari dua kelas sosial yang berbeda. Faktor sosial seperti: kelompok acuan, keluarga, serta peran dan status sosial. Kelompok acuan dapat berupa teman, tetangga, keluarga dan rekan kerja. Faktor pribadi yang dapat mempengaruhi pengambilan keputusan adalah usia, pekerjaan, ekonomi, dan gaya hidup. Faktor psikologis yang mempengaruhi pengambilan keputusan di antaranya motivasi dan kepercayaan dari pengambil keputusan itu sendiri.

\subsection{Pemilihan Moda}

Pemilihan moda merupakan model terpenting dalam perencanaan dan kebijakan transportasi yang menyangkut efisiensi pergerakan di daerah perkotaan, ruang yang harus disediakan kota untuk dijadikan prasarana transportasi, dan banyaknya pilihan moda transportasi yang dapat dipilih penduduk (Tamin, 1997).

Tamin, 1997 membagi moda transportasi menjadi 2 yaitu :

a. Umum

- Becak

- Kereta api

- Bus

b. Pribadi

- Mobil

- Sepeda motor

\subsection{Faktor Pemilihan Moda}

Menurut Tamin (1997), faktor-faktor yang mempengaruhi seseorang dalam memilih suatu moda transportasi dapat dibedakan atas empat kategori sebagai berikut : 
a. Ciri Pengguna Jalan

Beberapa faktor berikut ini mempengaruhi pemilihan moda:

1) Ketersediaan atau pemilikan kendaraan pribadi; semakin tinggi pemilikan kendaraan pribadi akan semakin kecil pula ketergantungan pada angkutan umum

2) Pemilikan Surat Izin Mengemudi (SIM)

3) Struktur rumah tangga (pasangan muda, keluarga dengan anak, pensiun, bujangan, dan lain-lain)

4) Pendapatan; semakin tinggi pendapatan akan semakin besar peluang menggunakan kendaraan pribadi

5) Faktor lain misalnya keharusan menggunakan mobil ke tempat bekerja dan keperluan mengantar anak sekolah.

b. Ciri Pergerakan

1) Tujuan pergerakan

Hal yang terjadi di negara sedang berkembang; orang masih tetap menggunakan mobil pribadi ke tempat kerja, meskipun lebih mahal, karena ketepatan waktu, kenyamanan, dan lain-lainnya tidak dapat dipenuhi oleh angkutan umum.

2) Waktu terjadinya pergerakan

Jika ingin bergerak pada tengah malam, pasti membutuhkan kendaraan pribadi karena pada saat itu angkutan umum tidak atau jarang beroperasi.

3) Jarak perjalanan

Semakin jauh perjalanan, semakin cenderung memilih angkutan umum dibandingkan dengan angkutan pribadi. Contohnya, untuk bepergian dari Jakarta ke Surabaya; meskipun mempunyai mobil pribadi namun lebih cenderung menggunakan angkutan umum (pesawat, kereta api, atau bus) karena jaraknya yang sangat jauh.

c. Ciri Fasilitas Moda Transportasi

Hal ini dapat dikelompokkan menjadi dua kategori yaitu :

1.) Faktor kuantitatif seperti:

- Waktu total perjalanan: waktu menunggu di tempat pemberhentian bus, waktu berjalan kaki ke tempat pemberhentian bus, waktu selama bergerak, dan lain-lain

- Biaya transportasi (tarif, biaya bahan bakar, dan lain-lain)

- Ketersediaan ruang dan tarif parkir.

2.) Faktor kualitatif yang cukup sukar menghitungnya, meliputi : 
- Kenyamanan

Kenyamanan didefinisikan sebagai berikut :

a.) Pelayanan yang sopan

b.) Terlindung dari cuaca buruk

C.) Mudah turun naik kendaraan

d.) Tersedia tempat duduk setiap saat

e.) Tidak bersesak-sesak

f.) Interior yang menarik

g.) Tempat duduk yang enak

- Keamanan

Keamanan memiliki arti yaitu :

a.) Terhindar dari kecelakaan

b.) Bebas dari kejahatan

- Keandalan dan keteraturan

Keandalan keteraturan didefinisikan sebagai:

a.) Setiap saat tersedia

b.) Waktu singkat

d. Ciri kota atau zona

Beberapa ciri yang dapat mempengaruhi pemilihan moda :

- Jarak dari pusat kota

- Kepadatan penduduk.

\subsection{Permintaan (Demand) Transportasi}

Masyarakat sebagai faktor utama dalam melakukan kegiatan perjalanan selalu ingin agar permintaannya terpenuhi. Menurut White (1976), permintaan yang ada dari masyarakat akan pemenuhan kebutuhan transportasi dipengaruhi oleh:
a. Pendapatan masing-masing orang
b. Tujuan Perjalanan
c. Usia
d. Perjalanan yang mendesak

\subsection{Penawaran (Supply) Transportasi}

Penawaran jasa transportasi meliputi tingkat pelayanan dan harga yang bertitik tolak pada pandangan bahwa kenaikan harga mengakibatkan meningkatnya jumlah yang dihasilkan dan ditawarkan untuk dijual. Tingkat pelayanan transportasi berhubungan erat dengan volume, seperti halnya dengan penetapan harga. 
Region, Vol. 14, No.1, Januari 2019: 13-36

Berkaitan dengan pelayanan angkutan orang, menurut Marvin (1979) ada beberapa faktor yang dapat mempengaruhi hal diatas adalah:

a. Keselamatan

b. Keteraturan

c. Harga yang terjangkau

d. Kenyamanan

\subsection{Neighbourhood Unit}

Clarence Perry menyimpulkan bahwa konsep Neighborhood Unit mempunyai tujuan utama untuk membuat interaksi sosial diantara penghuni lingkungan permukiman, sedangkan penataan fisik lingkungan merupakan cara untuk mencapai tujuan utama tersebut (Golany, 1976). Clarence Perry membuat ketetapan untuk terpenuhinya kebutuhan sosiopsikologis pemukim untuk menjamin agar terlaksananya konsep Neighbourhood Unit sebagai berikut :

a. Syarat kedekatan fisik

Dirumuskan dengan mengambil patokan besaran efektif komunitas dengan elemen :

1) Luas Wilayah

Teori ini mengidentifikasikan bahwa salah satu esensi dari konsep neighbourhood adalah kebutuhan dasar emosional manusia untuk berhubungan lebih erat dengan orang-orang disekitarnya, yang disebut sebagai kelompok primer (Brooms \& Selznick,1957 dalam Suryanto, 1989). Ukuran luas wilayah komunitas memungkinkan setiap penghuni mudah berkomunikasi dengan kelompok primernya karena dekatnya jarak capai dengan cukup berjalan kaki.

2) Jumlah penghuni

Ukuran jumlah penghuni yang memungkinkan tingkat saling tahu dan saling kenal diantara penghuni karena frekuensi kontak langsung yang tinggi.

3) Tingkat kepadatan bangunan atau penduduk

Perbandingan antara luas wilayah dan jumlah anggota menghasilkan suatu ukuran kepadatan yang memungkinkan tingkat ikatan fisik dan sosial komunitas tetap tinggi, dengan tetap menjaga keseimbangan dengan daya dukung alam.

b. Syarat ikatan sosial

Jika fasilitas sosial sebagai ikatan fisik tersebut sesuai dengan kebutuhan sebagian besar anggota lingkungan, maka ikatan fisik tersebut akan 
Salsabila Imtiyas dkk, Faktor-faktor yang...

berfungsi sebagai ikatan sosial karena kemampuannya untuk merangsang terciptanya kelompok primer.

c. Syarat jaminan keselamatan lingkungan, yaitu :

1) Neighbourhood Unit, terbebas dari lalu-lintas tembus dan kemungkinan adanya persimpangan.

2) Adanya pemisahan yang tegas antara jalur lintas kendaraan dan jalur pejalan kaki.

3) Keamanan menyeberang jalan, dilengkapi dengan sarana penyeberangan jalan dan ZoSS.

d. Syarat ketersediaan fasilitas pelayanan sosial.

Fasilitas pelayanan sosial yang disyaratkan dalam Neighbourhood Unit adalah fasilitas pelayanan sosial yang melayani kebutuhan harian. Suatu fasilitas pelayanan sebagai elemen fungsional neighbourhood dapat berperan jika memiliki jarak layanan yang mudah dicapai dengan berjalan kaki, dimana daya jangkau jarak layanan efektif setiap fasilitas pelayanan sosial akan mempengaruhi ukuran besaran neighbourhood. Diharapkan fasilitas sosial ini menjadi media terjadinya kontak langsung antara penghuni dalam frekuensi yang tinggi yaitu frekuensi harian. Fasilitas pelayanan tersebut antara lain adalah : Sekolah tingkat dasar, warung atau toko, tempat peribadatan, balai pengobatan, balai lingkungan dan kantor pemerintahan lokal (Rabindra, 1991).

\section{METODE PENELITIAN}

Pendekatan yang dilakukan peneliti untuk menganalisis faktor-faktor yang mempengaruhi pemilihan moda bermotor anak dalam mengakses sekolah dasar di Surakarta adalah pendekatan deduktif. Berikut merupakan tabel variabel penelitian :

Tabel 1. Operasional Variabel Penelitian

\begin{tabular}{|l|c|c|c|}
\hline No. & $\begin{array}{c}\text { Variabel } \\
\text { Penelitian }\end{array}$ & Definisi Operasional & Sumber \\
\hline 1. & $\begin{array}{c}\text { Kepemilikan moda } \\
\text { orang tua }\end{array}$ & $\begin{array}{c}\text { Tersedianya kendaraan } \\
\text { milik orang tua sebagai } \\
\text { sarana melakukan } \\
\text { perjalanan }\end{array}$ & $\begin{array}{c}\text { Tamin (1997), Ortuzar \& Willumsen } \\
\text { (1994) dalam Djakfar, et, al., (2010), } \\
\text { Papacostas \& Prevedouros (1993), } \\
\text { Kardiyali (1991), Saxena (1989), } \\
\text { Khisty \& B. Kent (1998), Miro (2005), } \\
\text { O'hagan (2006), Alfajar (2014), } \\
\text { Kotler (2003), Hasan (2004) }\end{array}$ \\
\hline 2. & $\begin{array}{c}\text { Kepemilikan } \\
\text { lisensi } \\
\text { mengemudi orang } \\
\text { tua }\end{array}$ & $\begin{array}{c}\text { Kepemilikan terhadap surat } \\
\text { izin mengemudi (SIM) orang } \\
\text { tua untuk mengemudikan } \\
\text { kendaraan }\end{array}$ & $\begin{array}{c}\text { Tamin (1997) Ortuzar \& Willumsen } \\
\text { (1994) dalam Djakfar, et, al., (2010), } \\
\text { Miro (2005), O'hagan (2006), Alfajar } \\
\text { (2014), Kotler (2003), Hasan (2004) }\end{array}$ \\
\hline 3. & Struktur keluarga & $\begin{array}{c}\text { Bentuk keluarga yang dapat } \\
\text { berupa pasangan muda, }\end{array}$ & $\begin{array}{c}\text { Tamin (1997) Ortuzar \& Willumsen } \\
\text { (1994) dalam Djakfar, et, al., (2010), }\end{array}$ \\
\hline
\end{tabular}


Region, Vol. 14, No.1, Januari 2019: 13-36

\begin{tabular}{|c|c|c|c|}
\hline No. & $\begin{array}{c}\text { Variabel } \\
\text { Penelitian }\end{array}$ & Definisi Operasional & Sumber \\
\hline & & $\begin{array}{c}\text { keluarga dengan anak, } \\
\text { pensiun, bujangan, dan lain- } \\
\text { lain }\end{array}$ & $\begin{array}{l}\text { Miro (2005), O'hagan (2006), Alfajar } \\
\text { (2014), Kotler (2003), Hasan (2004) }\end{array}$ \\
\hline 4. & Ukuran keluarga & $\begin{array}{l}\text { Jumlah anggota keluarga } \\
\text { dalam satu keluarga }\end{array}$ & $\begin{array}{c}\text { Miro (2005), Kardiyali (1991) } \\
\text { Khisty \& B. Kent (1998), } \\
\text { O’hagan (2006), Alfajar (2014), } \\
\text { Kotler (2003), Hasan (2004) }\end{array}$ \\
\hline 5. & $\begin{array}{l}\text { Jenis pekerjaan } \\
\text { orang tua }\end{array}$ & $\begin{array}{l}\text { Bentuk mata pencaharian } \\
\text { orang tua contohnya petani, } \\
\text { guru, dosen, dan lain-lain }\end{array}$ & $\begin{array}{c}\text { Ortuzar \& Willumsen (1994) dalam } \\
\text { Djakfar, et, al., (2010), Miro (2005), } \\
\text { O'hagan (2006), Alfajar (2014), } \\
\text { Kotler (2003), Hasan (2004) }\end{array}$ \\
\hline 6. & $\begin{array}{l}\text { Pendapatan orang } \\
\text { tua }\end{array}$ & $\begin{array}{c}\text { Jumlah } \\
\text { pemasukan/pendapatan } \\
\text { orang tua }\end{array}$ & $\begin{array}{r}\text { Tamin (1997), Ortuzar \& Willumsen } \\
\text { (1994) dalam Djakfar, et, al., (2010) } \\
\text { Saxena (1989), Miro (2005), } \\
\text { Papacostas \& Prevendouros (1993), } \\
\text { Kardiyali (1991), Khisty \& B. Kent } \\
\text { (1998), Gonzaga \& Viloria (1999), } \\
\text { O'hagan, Kotler (2003), Hasan (2004) } \\
\text { (2006), Alfajar (2014) }\end{array}$ \\
\hline 7. & Usia orang tua & $\begin{array}{l}\text { Umur orang tua, dapat } \\
\text { dikategorikan sebagai usia } \\
\text { muda, tua, dll }\end{array}$ & $\begin{array}{c}\text { Ortuzar \& Willumsen (1994) dalam } \\
\text { Djakfar, et, al., (2010), Saxena } \\
\text { (1989), Miro (2005), Gonzaga \& } \\
\text { Viloria (1999), O'hagan (2006), } \\
\text { Alfajar (2014), Kotler (2003), Hasan } \\
\text { (2004) }\end{array}$ \\
\hline 8. & $\begin{array}{l}\text { Jenis kelamin } \\
\text { orang tua yang } \\
\text { berperan }\end{array}$ & $\begin{array}{l}\text { Jenis kelamin orang tua } \\
\text { yang berperan } \\
\text { mengantarkan anaknya ke } \\
\text { sekolah, dapat dibedakan } \\
\text { menjadi dua yaitu } \\
\text { perempuan dan laki-laki }\end{array}$ & $\begin{array}{c}\text { Ortuzar \& Willumsen (1994) dalam } \\
\text { Djakfar, et, al., (2010), Saxena } \\
\text { (1989), Miro (2005), O’hagan (2006), } \\
\text { Alfajar (2014), Kotler (2003), Hasan } \\
\text { (2004) }\end{array}$ \\
\hline 9. & $\begin{array}{l}\text { Jenis kelamin } \\
\text { teman sebaya }\end{array}$ & $\begin{array}{l}\text { Jenis kelamin teman sebaya } \\
\text { dalam melakukan } \\
\text { perjalanan ke sekolah }\end{array}$ & $\begin{array}{c}\text { Ortuzar \& Willumsen (1994) dalam } \\
\text { Djakfar, et, al., (2010), Saxena } \\
\text { (1989), Miro (2005), Gunarsa \& } \\
\text { Gunarsa (2006), O'hagan (2006) } \\
\text {, Alfajar (2014), Kotler } \\
\text { (2003), Hasan (2004) }\end{array}$ \\
\hline 10. & $\begin{array}{l}\text { Jumlah pekerja } \\
\text { dalam keluarga }\end{array}$ & $\begin{array}{c}\text { Jumlah anggota keluarga } \\
\text { yang bekerja dalam satu } \\
\text { keluarga }\end{array}$ & $\begin{array}{c}\text { Papacostas \& Prevendouros (1993), } \\
\text { Gonzaga \& Viloria (1999), O'hagan } \\
\text { (2006), Alfajar (2014), Kotler (2003), } \\
\text { Hasan (2004) }\end{array}$ \\
\hline 11. & $\begin{array}{l}\text { Tujuan perjalanan } \\
\text { orang tua }\end{array}$ & $\begin{array}{l}\text { Maksud perjalanan yang } \\
\text { akan dilakukan oleh orang } \\
\text { tua seperti pergi bekerja, } \\
\text { berbelanja, tujuan sosial } \\
\text { dan lain-lain }\end{array}$ & $\begin{array}{c}\text { Tamin (1997), Ortuzar \& Willumsen } \\
\text { (1994) dalam Djakfar, et, al., (2010), } \\
\text { Saxena (1989), Miro (2005), } \\
\text { Papacostas \& Prevendouros (1993), } \\
\text { Morlok (1985), Kardiyali (1991), } \\
\text { Khisty \& B. Kent (1998), O’hagan } \\
\text { (2006), Alfajar (2014), Kotler (2003), } \\
\text { Hasan (2004) }\end{array}$ \\
\hline 12. & $\begin{array}{l}\text { Tujuan perjalanan } \\
\text { teman sebaya }\end{array}$ & $\begin{array}{l}\text { Tujuan teman sebaya dalam } \\
\text { melakukan perjalanan }\end{array}$ & $\begin{array}{c}\text { Tamin (1997), Ortuzar \& Willumsen } \\
\text { (1994) dalam Djakfar, et, al., (2010), } \\
\text { Saxena (1989), Miro (2005), } \\
\text { Papacostas \& Prevendouros (1993), } \\
\text { Morlok (1985), Kardiyali (1991), } \\
\text { Khisty \& B. Kent (1998), Gunarsa \& } \\
\text { Gunarsa (2006), O’hagan (2006) } \\
\text {, Alfajar (2014), Kotler } \\
\text { (2003), Hasan (2004) }\end{array}$ \\
\hline
\end{tabular}


Salsabila Imtiyas dkk, Faktor-faktor yang...

\begin{tabular}{|c|c|c|c|}
\hline No. & $\begin{array}{c}\text { Variabel } \\
\text { Penelitian }\end{array}$ & Definisi Operasional & Sumber \\
\hline 13. & $\begin{array}{l}\text { Tujuan perjalanan } \\
\text { ke sekolah }\end{array}$ & $\begin{array}{c}\text { Tujuan perjalanan yang } \\
\text { akan dilakukan menuju ke } \\
\text { sekolah }\end{array}$ & $\begin{array}{c}\text { Tamin (1997), Ortuzar \& Willumsen } \\
\text { (1994) dalam Djakfar, et, al., (2010), } \\
\text { Saxena (1989), Miro (2005), } \\
\text { Papacostas \& Prevendouros (1993), } \\
\text { Morlok (1985), Kardiyali (1991), } \\
\text { Khisty \& B. Kent (1998), O’hagan } \\
\text { (2006), Alfajar (2014), JF, Blackwell } \\
\text { \& W (1994), Gunarsa (1993) }\end{array}$ \\
\hline 14. & $\begin{array}{l}\text { Waktu terjadinya } \\
\text { perjalanan orang } \\
\text { tua }\end{array}$ & $\begin{array}{l}\text { Kapan terjadinya perjalanan } \\
\text { dilaksanakan, contohnya } \\
\text { pagi hari, siang hari, tengah } \\
\text { malam, hari libur, jam } \\
\text { puncak/tidak puncak, dan } \\
\text { lain-lain }\end{array}$ & $\begin{array}{c}\text { Tamin (1997), Ortuzar \& Willumsen } \\
\text { (1994) dalam Djakfar, et, al., (2010), } \\
\text { Saxena (1989), Miro (2005), } \\
\text { Papacostas \& Prevendouros (1993), } \\
\text { Khisty \& B. Kent (1998), O’hagan } \\
\text { (2006), Alfajar (2014), Kotler (2003), } \\
\text { Hasan (2004) }\end{array}$ \\
\hline 15. & $\begin{array}{l}\text { Waktu terjadinya } \\
\text { perjalanan teman } \\
\text { sebaya }\end{array}$ & $\begin{array}{l}\text { Kapan terjadinya perjalanan } \\
\text { teman sebaya dilaksanakan }\end{array}$ & $\begin{array}{c}\text { Tamin (1997), Ortuzar \& Willumsen } \\
\text { (1994) dalam Djakfar, et, al., (2010), } \\
\text { Saxena (1989), Miro (2005), } \\
\text { Papacostas \& Prevendouros (1993), } \\
\text { Khisty \& B. Kent (1998), Gunarsa \& } \\
\text { Gunarsa (2006), O’hagan (2006) } \\
\text {, Alfajar (2014), Kotler } \\
\text { (2003), Hasan (2004) }\end{array}$ \\
\hline 16. & $\begin{array}{l}\text { Waktu terjadinya } \\
\text { perjalanan ke } \\
\text { sekolah }\end{array}$ & $\begin{array}{l}\text { Kapan terjadinya perjalanan } \\
\text { menuju ke sekolah, } \\
\text { misalnya pada pukul } 7 \text { pagi, } \\
8 \text { pagi, dan lain-lain }\end{array}$ & $\begin{array}{c}\text { Tamin (1997), Ortuzar \& Willumsen } \\
\text { (1994) dalam Djakfar, et, al., (2010), } \\
\text { Saxena (1989), Miro (2005), } \\
\text { Papacostas \& Prevendouros (1993), } \\
\text { Khisty \& B. Kent (1998), O'hagan } \\
\text { (2006), Alfajar (2014), JF, Blackwell } \\
\text { \&W (1994), Gunarsa (1993) }\end{array}$ \\
\hline 17. & $\begin{array}{l}\text { Jarak perjalanan } \\
\text { ke sekolah }\end{array}$ & $\begin{array}{c}\text { Jarak dari tempat asal ke } \\
\text { lokasi sekolahan yang akan } \\
\text { dituju }\end{array}$ & $\begin{array}{c}\text { Tamin (1997), Ortuzar \& Willumsen } \\
\text { (1994) dalam Djakfar, et, al., (2010), } \\
\text { Saxena (1989), Miro (2005), } \\
\text { Papacostas \& Prevendouros (1993), } \\
\text { Kardiyali (1991), Khisty \& B. Kent } \\
\text { (1998), Gonzaga \& Viloria (1999), } \\
\text { Muller (2008), O’hagan (2006), } \\
\text { Alfajar (2014), JF, Blackwell \& W } \\
\text { (1994), Gunarsa (1993) }\end{array}$ \\
\hline 18. & $\begin{array}{l}\text { Waktu tempuh } \\
\text { perjalanan ke } \\
\text { sekolah }\end{array}$ & $\begin{array}{l}\text { Waktu total selama } \\
\text { perjalanan menuju ke } \\
\text { sekolahan. Untuk } \\
\text { transportasi umum, waktu } \\
\text { tempuh perjalanan terdiri } \\
\text { dari: } \\
\text { a. waktu yang dihabiskan } \\
\text { untuk berjalan menuju } \\
\text { kendaraan umum } \\
\text { b. waktu yang dihabiskan } \\
\text { untuk menunggu } \\
\text { kendaraan angkutan } \\
\text { umum } \\
\text { c. waktu yang dihabiskan } \\
\text { saat berada di angkutan } \\
\text { umum } \\
\text { d. waktu yang dihabiskan } \\
\text { untuk berpindah dari } \\
\text { satu kendaraan }\end{array}$ & $\begin{array}{c}\text { Tamin (1997), Ortuzar \& Willumsen } \\
\text { (1994) dalam Djakfar, et, al., (2010), } \\
\text { Saxena (1989), Miro (2005), } \\
\text { Papacostas \& Prevendouros (1993), } \\
\text { Morlok (1985), Kardiyali (1991), } \\
\text { Khisty \& B. Kent (1998), Wicaksana } \\
\text { (2015), O’hagan (2006), Alfajar } \\
\text { (2014), JF, Blackwell \& W (1994), } \\
\text { Gunarsa (1993) }\end{array}$ \\
\hline
\end{tabular}


Region, Vol. 14, No.1, Januari 2019: 13-36

\begin{tabular}{|c|c|c|c|}
\hline No. & $\begin{array}{c}\text { Variabel } \\
\text { Penelitian }\end{array}$ & Definisi Operasional & Sumber \\
\hline & & $\begin{array}{l}\text { angkutan umum ke } \\
\text { kendaraan angkutan } \\
\text { umum lainnya } \\
\text { e. waktu yang dihabiskan } \\
\text { untuk berjalan menuju } \\
\text { kendaraan umum }\end{array}$ & \\
\hline 19. & $\begin{array}{l}\text { Biaya perjalanan } \\
\text { ke sekolah }\end{array}$ & $\begin{array}{l}\text { Besarnya tarif angkutan } \\
\text { umum yang berlaku untuk } \\
\text { anak sekolahan, sedangkan } \\
\text { biaya perjalanan dengan } \\
\text { moda transportasi pribadi } \\
\text { meliputi komponen: biaya } \\
\text { bahan bakar, pelumas, } \\
\text { parkir, tol dan lain-lain }\end{array}$ & $\begin{array}{c}\text { Tamin (1997), Ortuzar \& Willumsen } \\
\text { (1994) dalam Djakfar, et, al., (2010), } \\
\text { Teknomo (1999), Miro (2005), } \\
\text { Papacostas \& Prevendouros (1993), } \\
\text { Morlok (1985), Kardiyali (1991), } \\
\text { Wicaksana (2015), Muller (2008), } \\
\text { O’hagan (2006), Alfajar (2014), JF, } \\
\text { Blackwell \& W (1994), Gunarsa } \\
\text { (1993) }\end{array}$ \\
\hline 20. & $\begin{array}{l}\text { Kenyamanan } \\
\text { moda menurut } \\
\text { pengalaman } \\
\text { orang tua }\end{array}$ & $\begin{array}{l}\text { Kenyamanan didefinisikan } \\
\text { sebagai berikut : } \\
\text { a. Pelayanan yang sopan } \\
\text { b. Terlindung dari cuaca } \\
\text { buruk } \\
\text { c. Mudah untuk naik atau } \\
\text { turun dari kendaraan } \\
\text { d. Tersedia tempat duduk } \\
\text { setiap saat } \\
\text { e. Tidak berdesak- } \\
\text { desakan } \\
\text { f. Interior yang menarik } \\
\text { g. Tempat duduk yang } \\
\text { enak }\end{array}$ & $\begin{array}{c}\text { Tamin (1997), Ortuzar \& Willumsen } \\
\text { (1994) dalam Djakfar, et, al., (2010), } \\
\text { Teknomo (1999), Black (1995), } \\
\text { Morlok (1985), Kardiyali (1991), } \\
\text { Wicaksana (2015), Hobbs (1995), } \\
\text { O'hagan (2006), Alfajar (2014), } \\
\text { Arroba (1998), Suryadi (2002) }\end{array}$ \\
\hline 21. & $\begin{array}{l}\text { Keamanan moda } \\
\text { menurut } \\
\text { pengalaman } \\
\text { orang tua }\end{array}$ & $\begin{array}{l}\text { Aman terhindar dari } \\
\text { kecelakaan dan bebas dari } \\
\text { kejahatan sehingga terjaga } \\
\text { keselamatan penumpang } \\
\text { kendaraaan }\end{array}$ & $\begin{array}{c}\text { Tamin (1997), Ortuzar \& Willumsen } \\
\text { (1994) dalam Djakfar, et, al., (2010), } \\
\text { Teknomo (1999), Black (1995), } \\
\text { Morlok (1985), Kardiyali (1991), } \\
\text { Wicaksana (2015), Hobbs (1995), } \\
\text { O'hagan (2006), Alfajar (2014), } \\
\text { Arroba (1998), Suryadi (2002) }\end{array}$ \\
\hline 22. & $\begin{array}{l}\text { Keandalan dan } \\
\text { keteraturan moda } \\
\text { menurut } \\
\text { pengalaman } \\
\text { orang tua }\end{array}$ & $\begin{array}{l}\text { Didefinisikan sebagai moda } \\
\text { transportasi yang setiap saat } \\
\text { tersedia dan dalam waktu } \\
\text { yang singkat }\end{array}$ & $\begin{array}{c}\text { Tamin (1997), Ortuzar \& Willumsen } \\
\text { (1994) dalam Djakfar, et, al., (2010), } \\
\text { Miro (2005), Hobbs (1995), O'hagan } \\
\text { (2006), Alfajar (2014), Arroba (1998), } \\
\text { Suryadi (2002) }\end{array}$ \\
\hline 23. & $\begin{array}{c}\text { Fasilitas parkir di } \\
\text { sekolah }\end{array}$ & $\begin{array}{l}\text { Tersedianya ruang untuk } \\
\text { meletakkaan kendaraan } \\
\text { (parkir) di sekolahan }\end{array}$ & $\begin{array}{c}\text { Miro (2005), Morlok (1985), O'hagan } \\
\text { (2006), Alfajar (2014), Kotler (2003), } \\
\text { Hasan (2004) }\end{array}$ \\
\hline 24. & $\begin{array}{l}\text { Tingkat } \\
\text { aksesibilitas } \\
\text { menurut } \\
\text { pengalaman } \\
\text { orang tua }\end{array}$ & $\begin{array}{c}\text { Tingkat/ukuran daya } \\
\text { hubung atau kemudahan } \\
\text { dalam pencapaian tempat } \\
\text { tujuan dari satu tempat ke } \\
\text { tempat lain }\end{array}$ & $\begin{array}{c}\text { Ortuzar \& Willumsen (1994) dalam } \\
\text { Djakfar, et, al., (2010), Miro (2005), } \\
\text { Papacostas \& Prevendouros (1993), } \\
\text { Kardiyali (1991), Wicaksana (2015), } \\
\text { Hobbs (1995), O’hagan (2006), } \\
\text { Alfajar (2014), Arroba (1998), } \\
\text { Suryadi (2002) }\end{array}$ \\
\hline 25. & $\begin{array}{c}\text { Efisiensi waktu ke } \\
\text { sekolah }\end{array}$ & $\begin{array}{l}\text { Ketepatan waktu moda } \\
\text { transportasi menuju ke } \\
\text { sekolahan }\end{array}$ & $\begin{array}{c}\text { Saxena (1989), Papacostas \& } \\
\text { Prevendouros (1993), Khisty \& B. } \\
\text { Kent (1998), O'hagan (2006), Alfajar } \\
\text { (2014), JF, Blackwell \& W (1994), } \\
\text { Gunarsa (1993) }\end{array}$ \\
\hline 26. & $\begin{array}{l}\text { Kepentingan } \\
\text { orang tua }\end{array}$ & $\begin{array}{l}\text { Keperluan atau keharusan } \\
\text { orang tua melakukan }\end{array}$ & $\begin{array}{c}\text { Tamin (1997), Saxena (1989), } \\
\text { O'hagan (2006), Alfajar (2014), JF, }\end{array}$ \\
\hline
\end{tabular}


Salsabila Imtiyas dkk, Faktor-faktor yang...

\begin{tabular}{|c|c|c|c|}
\hline No. & $\begin{array}{c}\text { Variabel } \\
\text { Penelitian }\end{array}$ & Definisi Operasional & Sumber \\
\hline & & $\begin{array}{l}\text { sesuatu yang berkaitan } \\
\text { dengan pemilihan moda }\end{array}$ & $\begin{array}{c}\text { Blackwell \& W (1994), Gunarsa } \\
\text { (1993) }\end{array}$ \\
\hline 27. & $\begin{array}{l}\text { Status (prestise) } \\
\text { dari orang tua }\end{array}$ & $\begin{array}{l}\text { Kedudukan atau identitas } \\
\text { pribadi orang tua yang } \\
\text { mempengaruhi dalam } \\
\text { pemilihan moda }\end{array}$ & $\begin{array}{l}\text { Black (1995), Kardiyali (1991), } \\
\text { O'hagan (2006), Alfajar (2014), } \\
\text { Kotler (2003) JF, Blackwell \& W } \\
\text { (1994) Munandar (2004) }\end{array}$ \\
\hline 28. & $\begin{array}{c}\text { Jalan bebas lalu } \\
\text { lintas menerus } \\
\text { menurut } \\
\text { pengetahuan } \\
\text { orang tua }\end{array}$ & $\begin{array}{l}\text { Terbebas dari lalu-lintas } \\
\text { tembus dan kemungkinan } \\
\text { adanya persimpangan }\end{array}$ & $\begin{array}{c}\text { Rabindra (1991), JF, Blackwell \& W } \\
\text { (1994), Gunarsa (1993), O’hagan } \\
\text { (2006), Alfajar (2014) }\end{array}$ \\
\hline 29. & $\begin{array}{l}\text { Pemisahan jalur } \\
\text { pejalan kaki dan } \\
\text { kendaraan } \\
\text { bermotor menurut } \\
\text { pengetahuan } \\
\text { orang tua }\end{array}$ & $\begin{array}{c}\text { Adanya pemisah jalur } \\
\text { pejalan kaki dan kendaraan } \\
\text { bermotor di jalan }\end{array}$ & $\begin{array}{c}\text { Rabindra (1991), JF, Blackwell \& W } \\
\text { (1994), Gunarsa (1993), O’hagan } \\
\text { (2006), Alfajar (2014) }\end{array}$ \\
\hline 30. & $\begin{array}{c}\text { Keamanan anak } \\
\text { menyeberang } \\
\text { jalan menurut } \\
\text { pengetahuan } \\
\text { orang tua }\end{array}$ & $\begin{array}{l}\text { Adanya sarana } \\
\text { penyeberangan jalan dan } \\
\text { dilengkapi ZoSS. }\end{array}$ & $\begin{array}{c}\text { Rabindra (1991), JF, Blackwell \& W } \\
\text { (1994), Gunarsa (1993), O’hagan } \\
\text { (2006), Alfajar (2014) }\end{array}$ \\
\hline
\end{tabular}

Sumber : Elaborasi dari berbagai sumber, 2017

Metode penelitian yang akan dilakukan pada penelitian ini adalah metode primer menyebarkan kuisioner melalui kumpulan pertanyaan yang disebarkan kepada responden secara langsung. Daftar pertanyaan dalam kuisioner penelitian ini menggunakan skala nilai Likert untuk setiap jawaban pertanyaan. Berikut merupakan skala nilai jawaban dalam kuisioner menggunakan skala Likert :

Tabel 2. Skala Nilai Likert

\begin{tabular}{|c|c|}
\hline Penilaian & Nilai \\
\hline Sangat Setuju & 5 \\
\hline Setuju & 4 \\
\hline Netral & 3 \\
\hline Tidak Setuju & 2 \\
\hline Sangat Tidak Setuju & 1 \\
\hline
\end{tabular}

Sumber: Supranto, 2003

Dalam penelitian ini, populasi yang akan diteliti adalah anak yang sedang menempuh pendidikan sekolah dasar di dalam neighbourhood unit yang menggunakan kendaraan bermotor di Kota Surakarta yaitu sebanyak 10.261 anak. Dengan menggunakan proporsional sampling penelitian didapatkan sampel sejumlah 138 sampel.

Pada penelitian ini digunakan teknik analisis faktor untuk mengetahui faktor-faktor yang mempengaruhi pemilihan moda bermotor anak dalam mengakses sekolah dasar di Kota Surakarta. Penelitian ini menggunakan alat bantu software SPSS untuk pengolahan data dan pengerjaan analisis faktor. Berikut merupakan tahapan dalam analisis faktor:

a. Menentukan variabel yang akan dianalisis 
Region, Vol. 14, No.1, Januari 2019: 13-36

b. Menguji validitas dan realibilitas variabel yang akan dianalisis

c. Menguji KMO, Bartlett dan MSA Variabel yang Telah Ditentukan

d. Melakukan faktoring dan rotasi

e. Interpretasi faktor yang telah terbentuk

\section{HASIL DAN PEMBAHASAN}

Kota Surakarta memiliki 263 sekolah dasar/sederajat dengan jenis sekolah dasar negeri, sekolah dasar swasta, Madrasah Ibtidaiyah (MI) serta sekolah bagi siswa berkebutuhan khusus (SLB). 263 sekolah dasar tersebut tersebar pada 109 neighbourhood unit Kota Surakarta. Berikut merupakan peta penyebaran sekolah dasar dan batasan neighbourhood unit Kota Surakarta :

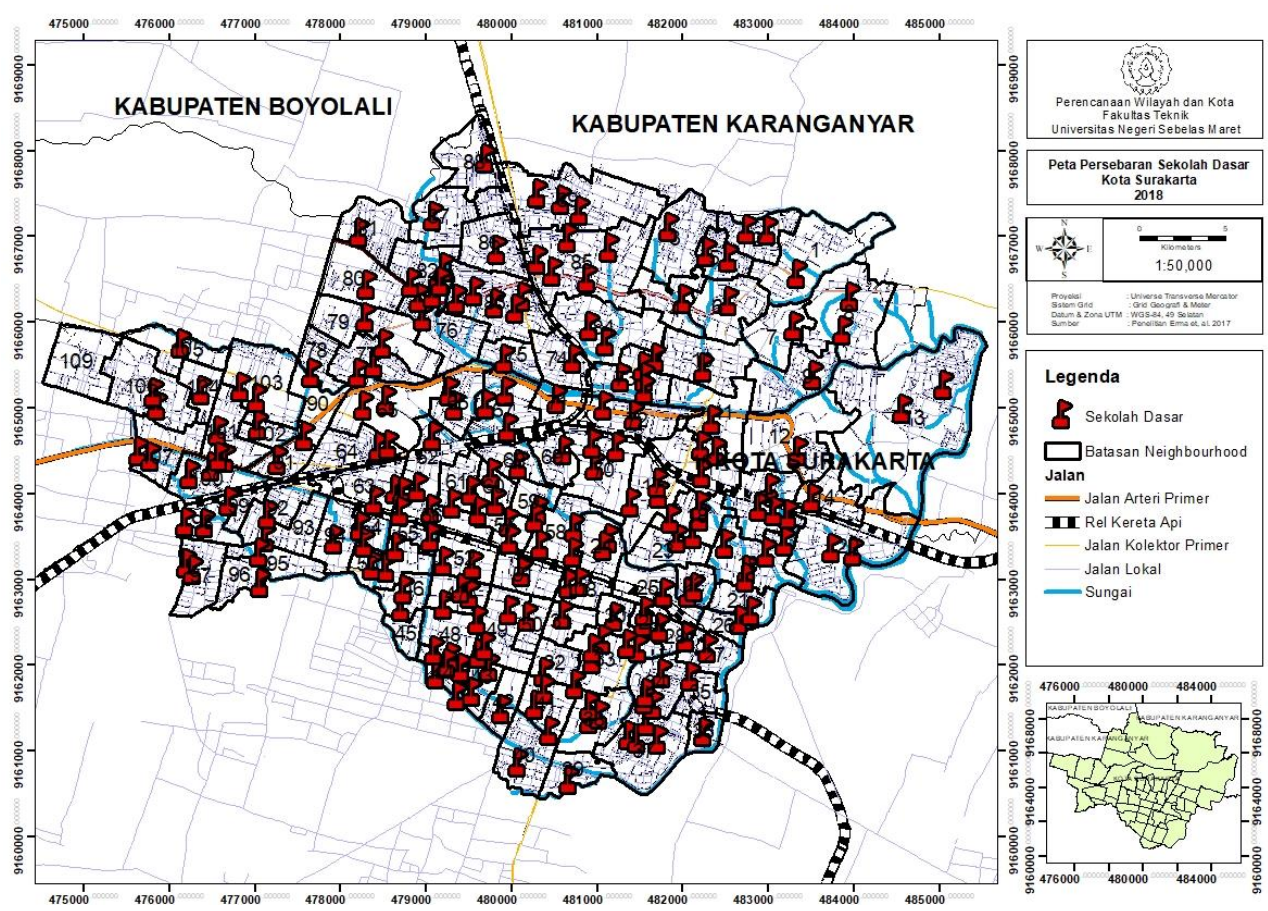

Gambar 1. Peta Persebaran Sekolah Dasar di Kota Surakarta

Pada tahap awal analisis faktor, 138 kuisioner akan diuji validitas dan reliabilitasnya. Hasil uji validitas dan reliabilitas menujukkan nilai Cronbach's Alpha yang menunjukkan reliabilitas berada pada angka 0,927 dan 30 butir pertanyaan yang disebarkan telah reliabel. Hal ini berdasarkan standar dimana nilai Cronbach's Alpha harus >0,8 agar dapat dikatakan reliabel.

Tabel 4.1 Hasil Uji Realibilitas

\section{Reliability Statistics}

\begin{tabular}{|r|r|}
\hline Cronbach's Alpha & N of Items \\
\hline .927 & 30 \\
\hline
\end{tabular}

Sumber : Analisis, 2018

Berdasarkan tabel diatas, maka dapat disimpulkan bahwa 30 pertanyaan yang diajukan dalam penelitian ini sudah reliabel. Dalam hal ini diartikan bahwa 30 
Salsabila Imtiyas dkk, Faktor-faktor yang...

pertanyaan yang diajukan dalam penelitian ini dapat dipercaya sebagai alat pengumpulan dan mampu mengungkap informasi yang sebenarnya di lapangan.

Dalam melihat faktor yang terbentuk, maka dapat dilihat pada nilai Eigenvaluenya yaitu harus $>1$. Jika nilai Eigenvaluenya $<1$, maka hal ini tidak tepat. Eigenvalue menunjukkan kepentingan reatif masing-masing faktor dalam menghitung varians dari total variabel yang ada. Eigenvalue diurutkan dari nilai yang terbesar sampai nilai yang terkecil.

Tabel 3. Total Variance Explained

Total Variance Explained

\begin{tabular}{|c|c|c|c|c|c|c|c|c|c|}
\hline \multirow[t]{2}{*}{$\begin{array}{l}\text { Compone } \\
\text { nt }\end{array}$} & \multicolumn{3}{|c|}{ Initial Eigenvalues } & \multicolumn{3}{|c|}{$\begin{array}{l}\text { Extraction Sums of Squared } \\
\text { Loadings }\end{array}$} & \multicolumn{3}{|c|}{$\begin{array}{c}\text { Rotation Sums of Squared } \\
\text { Loadings }\end{array}$} \\
\hline & Total & $\begin{array}{c}\% \text { of } \\
\text { Varianc } \\
\mathrm{e}\end{array}$ & $\begin{array}{l}\text { Cumulati } \\
\text { ve } \%\end{array}$ & Total & $\begin{array}{c}\% \text { of } \\
\text { Variance }\end{array}$ & $\begin{array}{l}\text { Cumulati } \\
\text { ve } \%\end{array}$ & Total & $\begin{array}{c}\% \text { of } \\
\text { Varianc } \\
\mathrm{e}\end{array}$ & $\begin{array}{l}\text { Cumulati } \\
\text { ve } \%\end{array}$ \\
\hline 1 & 10.178 & 33.927 & 33.927 & 10.178 & 33.927 & 33.927 & 4.340 & 14.466 & 14.466 \\
\hline 2 & 3.045 & 10.151 & 44.078 & 3.045 & 10.151 & 44.078 & 3.873 & 12.909 & 27.375 \\
\hline 3 & 1.941 & 6.469 & 50.547 & 1.941 & 6.469 & 50.547 & 3.188 & 10.627 & 38.002 \\
\hline 4 & 1.517 & 5.058 & 55.605 & 1.517 & 5.058 & 55.605 & 2.844 & 9.479 & 47.480 \\
\hline 5 & 1.442 & 4.807 & 60.412 & 1.442 & 4.807 & 60.412 & 2.569 & 8.563 & 56.044 \\
\hline 6 & 1.253 & 4.177 & 64.589 & 1.253 & 4.177 & 64.589 & 2.069 & 6.896 & 62.940 \\
\hline 7 & 1.029 & 3.430 & 68.020 & 1.029 & 3.430 & 68.020 & 1.524 & 5.080 & 68.020 \\
\hline 8 & .945 & 3.149 & 71.168 & & & & & & \\
\hline 9 & .892 & 2.973 & 74.141 & & & & & & \\
\hline 10 & .780 & 2.600 & 76.741 & & & & & & \\
\hline 11 & .725 & 2.418 & 79.160 & & & & & & \\
\hline $\operatorname{dim}_{12}$ & .656 & 2.187 & 81.346 & & & & & & \\
\hline 13 & .585 & 1.950 & 83.297 & & & & & & \\
\hline 14 & .556 & 1.854 & 85.151 & & & & & & \\
\hline 15 & .517 & 1.722 & 86.872 & & & & & & \\
\hline 16 & .494 & 1.647 & 88.520 & & & & & & \\
\hline 17 & .468 & 1.560 & 90.080 & & & & & & \\
\hline 18 & .408 & 1.359 & 91.439 & & & & & & \\
\hline 19 & .349 & 1.162 & 92.601 & & & & & & \\
\hline 20 & .337 & 1.123 & 93.724 & & & & & & \\
\hline 21 & .292 & .972 & 94.696 & & & & & & \\
\hline 22 & .252 & .840 & 95.536 & & & & & & \\
\hline 23 & .235 & .783 & 96.319 & & & & & & \\
\hline 24 & .218 & .727 & 97.045 & & & & & & \\
\hline
\end{tabular}


Region, Vol. 14, No.1, Januari 2019: 13-36

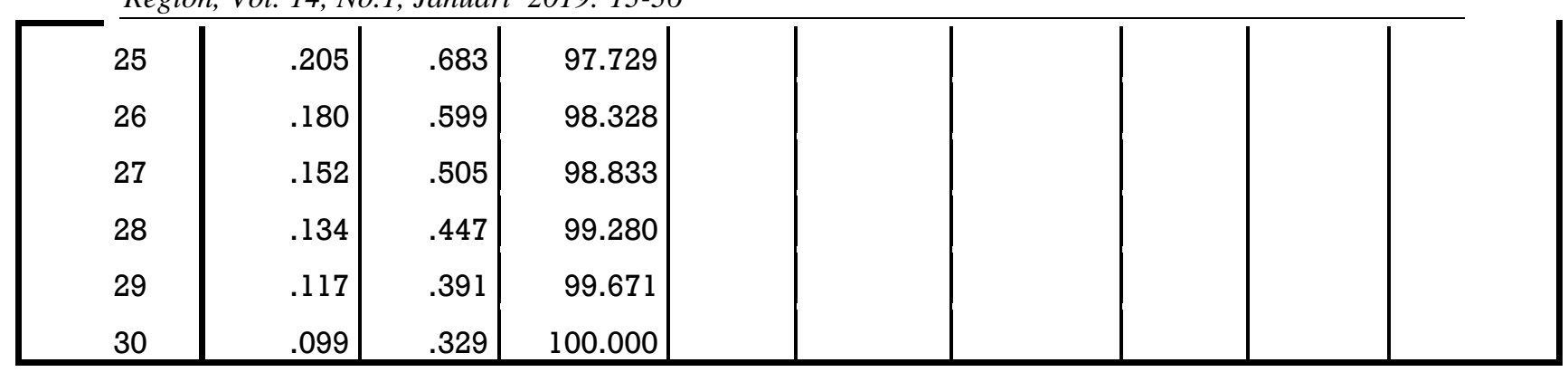

Extraction Method: Principal Component Analysis.

Sumber : Analisis, 2018

Pada tabel diatas, dapat dilihat bahwa 30 variabel yang ada telah dimasukkan ke dalam analisis faktor. Variabel-variabel tersebut selanjutnya diproses menggunakan analisis faktor yang akan menghasilkan jumlah faktor yang akan digunakan dalam analisis faktor dalam penelitian ini. Dari tabel diatas, dapat dilihat bahwa hanya hingga 7 faktor yang berada diatas 1. Maka dari itu, dapat disimpulkan bahwa faktor yang akan digunakan dalam penelitian ini adalah berjumlah 7 faktor. Dimana didalam sebuah faktor terdapat beberapa variabelvariabel yang berkelompok yang memiliki korelasi yang tinggi satu sama lainnya. Tahap selanjutnya adalah dengan melihat Component Matrix hasil rotasi (Rotated Component Matriks) yang dapat memperlihatkan distribusi variabel-variabel yang lebih jelas dan nyata. Berikut ini merupakan tabel dan juga penjelasan variabelvariabel tersebut tergolong ke dalam faktor yang mana.

Tabel 4 Rotated Component Matrix

Rotated Component Matrix ${ }^{a}$

\begin{tabular}{|c|c|c|c|c|c|c|c|}
\hline & \multicolumn{7}{|c|}{ Component } \\
\hline & 1 & 2 & 3 & 4 & 5 & 6 & 7 \\
\hline $\begin{array}{l}\text { Kepemilikan_moda_ora } \\
\text { ng tua }\end{array}$ & .349 & .053 & .015 & .045 & .128 & .780 & .107 \\
\hline $\begin{array}{l}\text { Kepemilikan lisensi } \\
\text { mengemudi orang tua }\end{array}$ & .106 & .223 & .080 & 146 & .046 & .867 & -.050 \\
\hline Struktur keluarga & .677 & .180 & .315 & .129 & .132 & .222 & -.029 \\
\hline Ukuran keluarga & .762 & .271 & .168 & .015 & .200 & .130 & .088 \\
\hline $\begin{array}{l}\text { Jenis pekerjaan orang } \\
\text { tua }\end{array}$ & .799 & .227 & .032 & .003 & .354 & .076 & .090 \\
\hline Pendapatan orang tua & .704 & .254 & -.085 & .111 & .126 & .191 & .200 \\
\hline Usia orang tua & .687 & .385 & .164 & .093 & -.086 & .248 & .228 \\
\hline $\begin{array}{l}\text { Jenis kelamin orang tua } \\
\text { yang berperan }\end{array}$ & .604 & .113 & .441 & .167 & -.093 & -.016 & .182 \\
\hline $\begin{array}{l}\text { Jenis kelamin teman } \\
\text { sebaya }\end{array}$ & .248 & .083 & .757 & -.097 & .073 & .126 & .000 \\
\hline
\end{tabular}




\begin{tabular}{|c|c|c|c|c|c|c|c|}
\hline & & & & alsabila Im & $d k k, F c$ & -faktor $y$ & \\
\hline $\begin{array}{l}\text { Jumlah pekerja dalam } \\
\text { keluarga }\end{array}$ & .472 & .191 & .554 & .323 & -.196 & .036 & .027 \\
\hline $\begin{array}{l}\text { Tujuan perjalanan } \\
\text { orang tua }\end{array}$ & .312 & .578 & .382 & .142 & -.061 & .074 & .147 \\
\hline $\begin{array}{l}\text { Tujuan perjalanan } \\
\text { teman sebaya }\end{array}$ & .051 & .137 & .878 & .039 & .160 & -.037 & .090 \\
\hline $\begin{array}{l}\text { Tujuan perjalanan ke } \\
\text { sekolah }\end{array}$ & .255 & .490 & .129 & .292 & .214 & .136 & -.096 \\
\hline $\begin{array}{l}\text { Waktu terjadinya } \\
\text { perjalanan orang tua }\end{array}$ & .218 & .756 & .206 & .145 & -.035 & .099 & .087 \\
\hline $\begin{array}{lr}\text { Waktu } & \text { terjadinya } \\
\text { perjalanan } & \text { teman } \\
\text { sebaya } & \end{array}$ & .028 & .243 & .810 & -.003 & .014 & .046 & .091 \\
\hline $\begin{array}{l}\text { Waktu terjadinya } \\
\text { perjalanan ke sekolah }\end{array}$ & .040 & .636 & .293 & .125 & .211 & .132 & .154 \\
\hline $\begin{array}{l}\text { Jarak perjalanan ke } \\
\text { sekolah }\end{array}$ & .281 & .730 & .038 & .113 & .215 & .034 & -.094 \\
\hline $\begin{array}{l}\text { Waktu tempuh } \\
\text { perjalanan ke sekolah }\end{array}$ & .323 & .654 & .062 & .172 & .271 & .037 & .082 \\
\hline $\begin{array}{l}\text { Biaya perjalanan ke } \\
\text { sekolah }\end{array}$ & .244 & .542 & .176 & .030 & .156 & .404 & .088 \\
\hline $\begin{array}{l}\text { Kenyamanan moda } \\
\text { menurut pengalaman } \\
\text { orang tua }\end{array}$ & .127 & .174 & .011 & .531 & .273 & .388 & -.217 \\
\hline $\begin{array}{l}\text { Keamanan moda } \\
\text { menurut pengalaman } \\
\text { orang tua }\end{array}$ & .255 & .252 & .031 & .313 & .662 & .105 & .147 \\
\hline $\begin{array}{lr}\text { Keandalan } & \text { dan } \\
\text { keteraturan } & \text { moda } \\
\text { menurut pengalaman } \\
\text { orang tua }\end{array}$ & -.043 & .138 & .270 & .139 & .681 & .267 & .358 \\
\hline $\begin{array}{l}\text { Fasilitas parkir di } \\
\text { sekolah }\end{array}$ & .400 & .081 & .119 & .206 & .581 & .116 & -.339 \\
\hline $\begin{array}{ll}\text { Tingkat aksesibilitas } \\
\text { menurut pengalaman } \\
\text { orang tua }\end{array}$ & .109 & .195 & -.064 & .336 & .690 & -.024 & -.088 \\
\hline $\begin{array}{l}\text { Efisiensi waktu ke } \\
\text { sekolah }\end{array}$ & -.046 & .448 & -.174 & 649 & .136 & .104 & .137 \\
\hline Kepentingan orang tua & .286 & .288 & .015 & .282 & .077 & .151 & .520 \\
\hline $\begin{array}{l}\text { Status (prestise) dari } \\
\text { orang tua }\end{array}$ & .289 & .041 & .224 & .107 & .030 & -.049 & .771 \\
\hline
\end{tabular}


Region, Vol. 14, No.1, Januari 2019: 13-36

\begin{tabular}{|c|c|c|c|c|c|c|c|}
\hline $\begin{array}{l}\text { Jalan bebas lalu lintas } \\
\text { menerus menurut } \\
\text { pengetahuan orang tua }\end{array}$ & .134 & -.019 & .094 & .697 & .011 & -.039 & .213 \\
\hline $\begin{array}{l}\text { Pemisahan jalur pejalan } \\
\text { kaki dan kendaraan } \\
\text { bermotor menurut } \\
\text { pengetahuan orang tua }\end{array}$ & .044 & .172 & .091 & .684 & .294 & .121 & -.049 \\
\hline $\begin{array}{l}\text { Keamanan anak } \\
\text { menyeberang jalan } \\
\text { menurut pengetahuan } \\
\text { orang tua }\end{array}$ & .105 & .204 & -.021 & .658 & .354 & .051 & .126 \\
\hline
\end{tabular}

Extraction Method: Principal Component Analysis.

Rotation Method: Varimax with Kaiser Normalization.

a. Rotation converged in 12 iterations.

Sehingga didapatkan 30 variabel yang ada telah direduksi sehingga terdiri dari 7 kelompok faktor, yaitu:

a) Kelompok faktor 1 terdiri dari: Struktur keluarga, Ukuran keluarga, Jenis pekerjaan orang tua, Pendapatan orang tua, Usia orang tua, Jenis kelamin orang tua yang berperan

b) Kelompok faktor 2 terdiri dari: Waktu terjadinya perjalanan ke sekolah, Jarak perjalanan ke sekolah, Waktu tempuh perjalanan ke sekolah, Biaya perjalanan ke sekolah, Tujuan perjalanan orang tua, Waktu terjadinya perjalanan orang tua.

c) Kelompok faktor 3 terdiri dari: Jenis kelamin teman sebaya, Jumlah pekerja dalam keluarga, Tujuan perjalanan teman sebaya, Waktu terjadinya perjalanan teman sebaya

d) Kelompok faktor 4 terdiri dari: Tujuan perjalanan ke sekolah, Kenyamanan moda menurut pengalaman orang tua, Efisiensi waktu ke sekolah, Jalan bebas lalu lintas menerus menurut pengetahuan orang tua, Pemisahan jalur pejalan kaki dan kendaraan bermotor menurut pengetahuan orang tua, Keamanan anak menyeberang jalan menurut pengetahuan orang tua

e) Kelompok faktor 5 terdiri dari: Keamanan moda menurut pengalaman orang tua, Keandalan dan keteraturan moda menurut pengalaman orang tua, Fasilitas parkir di sekolah, Tingkat aksesibilitas menurut pengalaman orang tua

f) Kelompok faktor 6 terdiri dari: Kepemilikan moda orang tua, Kepemilikan lisensi mengemudi orang tua

g) Kelompok faktor 7 terdiri dari: Kepentingan orang tua, Status (prestise) dari orang tua. 
Salsabila Imtiyas dkk, Faktor-faktor yang...

Tabel 5 Component Transformation Matrix

Component Transformation Matrix

\begin{tabular}{|c|r|r|r|r|r|r|r|}
\hline Component & \multicolumn{1}{|c|}{1} & \multicolumn{1}{c|}{2} & \multicolumn{1}{l|}{3} & \multicolumn{1}{c|}{4} & \multicolumn{1}{c|}{5} & \multicolumn{1}{c|}{6} & \multicolumn{1}{c|}{7} \\
\hline 1 & .546 & .530 & .324 & .347 & .312 & .270 & .160 \\
2 & -.278 & .055 & -.637 & .504 & .474 & .110 & -.151 \\
$\operatorname{dim} 3$ & -.631 & .109 & .600 & .342 & .146 & -.298 & .053 \\
ensi 4 & -.172 & -.044 & .272 & -.360 & .336 & .539 & -.601 \\
on0 5 & .331 & -.750 & .196 & .122 & .482 & -.191 & .074 \\
6 & -.182 & -.354 & .088 & .313 & -.322 & .700 & .377 \\
7 & .235 & -.121 & .097 & .515 & -.455 & -.095 & -.663 \\
\hline
\end{tabular}

Extraction Method: Principal Component Analysis.

Rotation Method: Varimax with Kaiser Normalization.

Sumber : Analisis, 2018

Dari tabel diatas dapat dilihat bahwa pada diagonal faktor (komponen), yakni 0,$546 ; 0,504 ; 0,600 ; 0,539 ; 0,482 ; 0,700 ;$ dan 0,515. Dari ketujuh kelompok faktor ini hanya kelompok lima yang tidak memiliki nilai diatas 0,5 , sehingga hanya enam kelompok faktor ini cukup untuk mewakili atau merepresentasikan faktor-faktor yang berpengaruh dalam penelitian ini.

Terdapat enam kelompok faktor yang mempengaruhi pemilihan moda bermotor anak dalam mengakses sekolah dasar di Kota Surakarta. Keenam kelompok faktor ini merupakan gabungan faktor yang memiliki korelasi tinggi satu dengan yang lainnya.

Kelompok faktor paling utama yang mempengaruhi pemilihan moda bermotor anak dalam mengakses sekolah dasar di Kota Surakarta adalah kelompok faktor 1 yang terdiri dari struktur keluarga, ukuran keluarga, jenis pekerjaan orang tua, pendapatan orang tua, usia orang tua, dan jenis kelamin orang tua yang berperan. Hal tersebut ditunjukkan oleh kelompok faktor 1 dengan nilai keragaman data sebesar 33,927\%. Dalam kelompok faktor 1, variabel jenis pekerjaan orang tua memiliki nilai loading factor tertinggi yaitu sebesar 0,799. Hal ini menunjukkan bahwa variabel jenis pekerjaan orang tua merupakan variabel yang sangat mempengaruhi pemilihan moda bermotor anak dalam mengakses sekolah dasar di Kota Surakarta. Uraian tersebut sejalan dengan teori dari Bruton (1975) dalam Warpani (1990) bahwa faktor sosial ekonomi berupa ukuran keluarga, struktur kelamin, usia anggota keluarga, proporsi angkatan kerja perempuan yang kawin, jenis kekayaan yang dimiliki, dan jenis pekerjaaan adalah faktor yang mempengaruhi pemilihan moda. Dalam hal ini untuk faktor yang sangat berpengaruh dalam pemilihan moda bermotor anak dalam mengakses sekolah dasar di Kota Surakarta yaitu pekerjaan orang tua. 
Region, Vol. 14, No.1, Januari 2019: 13-36

Kelompok faktor yang memiliki nilai tertinggi kedua adalah kelompok faktor 2 yang terdiri dari waktu terjadinya perjalanan ke sekolah, jarak perjalanan ke sekolah, waktu tempuh perjalanan ke sekolah, biaya perjalanan ke sekolah, tujuan perjalanan orang tua, waktu terjadinya perjalanan orang tua yang memiliki nilai keragaman data sebesar 10,151\%. Dari keenam faktor yang di kelompok faktor 2, faktor yang memiliki pengaruh paling besar adalah faktor waktu perjalanan orang tua dengan nilai 0,756. Hal ini berarti dalam kelompok faktor 2, faktor waktu perjalanan orang tua merupakan faktor yang paling berpengaruh dalam pemilihan moda bermotor anak dalam mengakses sekolah dasar di Kota Surakarta.

Kelompok faktor 3 yang terdiri dari jenis kelamin teman sebaya, jumlah pekerja dalam keluarga, tujuan perjalanan teman sebaya, waktu terjadinya perjalanan teman sebaya. Kelompok faktor ini mampu menjelaskan keragaman data sebesar 6,469\%. Artinya pemilihan moda bermotor anak dalam mengakses sekolah dasar di Kota Surakarta dipengaruhi oleh kelompok faktor 3 sebesar 6,469\%. Dalam kelompok faktor 3 , faktor tujuan perjalanan teman sebaya memiliki nilai loading factor tertinggi yaitu sebesar 0,878 . Hal ini berarti dalam kelompok faktor 3 , faktor tujuan perjalanan teman sebaya merupakan faktor yang paling berpengaruh dalam pemilihan moda bermotor anak dalam mengakses sekolah dasar di Kota Surakarta.

Kelompok faktor 4 yang terdiri dari tujuan perjalanan ke sekolah, kenyamanan moda, efisiensi waktu ke sekolah, jalan bebas lalu lintas menerus, pemisahan jalur pejalan kaki dan kendaraan bermotor, keamanan anak menyeberang jalan. Kelompok faktor ini mampu menjelaskan keragaman data sebesar 5,058\%. Artinya pemilihan moda bermotor anak dalam mengakses sekolah dasar di Kota Surakarta dipengaruhi oleh kelompok faktor 4 sebesar 5,058\%. Dalam kelompok faktor 4, faktor jalan bebas lalu lintas menerus memiliki nilai loading factor tertinggi yaitu sebesar 0,697. Hal ini berarti dalam kelompok faktor 4, faktor jalan bebas lalu lintas menerus merupakan faktor yang paling berpengaruh dalam pemilihan moda bermotor anak dalam mengakses sekolah dasar di Kota Surakarta.

Kelompok faktor 6 yang terdiri dari kepemilikan moda orang tua, kepemilikan lisensi mengemudi orang tua. Kelompok faktor ini mampu menjelaskan keragaman data sebesar 4,177\%. Artinya pemilihan moda bermotor anak dalam mengakses sekolah dasar di Kota Surakarta dipengaruhi oleh kelompok faktor 6 sebesar 4,177\%. Dalam kelompok faktor 6, faktor kepemilikan lisensi mengemudi orang tua memiliki nilai loading factor tertinggi yaitu sebesar 0,867. Hal ini berarti dalam kelompok faktor 6 , faktor kepemilikan lisensi mengemudi orang tua merupakan faktor yang paling berpengaruh dalam pemilihan moda bermotor anak dalam mengakses sekolah dasar di Kota Surakarta. 
Salsabila Imtiyas dkk, Faktor-faktor yang...

Kelompok faktor 7 yang terdiri dari kepentingan orang tua, status (prestise) dari orang tua. Kelompok faktor ini mampu menjelaskan keragaman data sebesar 3,430\%. Artinya pemilihan moda bermotor anak dalam mengakses sekolah dasar di Kota Surakarta dipengaruhi oleh kelompok faktor 7 sebesar 3,430\%. Dalam kelompok faktor 7, faktor Status (prestise) dari orang tua memiliki nilai loading factor tertinggi yaitu sebesar 0,867. Hal ini berarti dalam kelompok faktor 6, faktor Status (prestise) dari orang tua merupakan faktor yang paling berpengaruh dalam pemilihan moda bermotor anak dalam mengakses sekolah dasar di Kota Surakarta.

\section{KESIMPULAN}

Pada bulan Juli 2017, Kota Surakarta ditetapkan sebagai Surakarta Kota Layak Anak untuk kategori Utama. Kota Surakarta sebagai kota layak anak harus memenuhi kebutuhan layak anak hingga pada skala lingkungan (neighbourhood unit). Salah satu fasilitas sosial dasar untuk anak yang penting dan harus tersedia di neighbourhood unit adalah sekolah dasar. Meskipun terdapat ketersediaan fasilitas sekolah dasar di dalam neighbourhood unit dan keterpenuhan kriteria kota layak anak, namun masih adanya masyarakat yang memilih menggunakan kendaraan bermotor untuk mengakses sekolah dasar setiap hari yang mengakibatkan adanya emisi gas buang. Hal tersebut sebenarnya bisa diminimalisir dengan kemampuan berjalan kaki anak dalam mengakses sekolah dasar. Penelitian ini menjelaskan mengenai faktor-faktor yang mempengaruhi pemilihan moda bermotor anak dalam mengakses sekolah dasar di Kota Surakarta. Berdasarkan pembahasan dan analisis dalam penelitian ini dapat disimpulkan bahwa melalui analisis faktor dapat diperoleh 6 kelompok faktor yang mempengaruhi pemilihan moda bermotor anak dalam mengakses sekolah dasar di Kota Surakarta.

Kelompok faktor pertama memiliki pengaruh paling besar dalam mempengaruhi pemilihan moda bermotor anak dalam mengakses sekolah dasar di Kota Surakarta dengan nilai sebesar 33,927\%. Kelompok faktor 1 terdiri dari struktur keluarga, ukuran keluarga, jenis pekerjaan orang tua, pendapatan orang tua, usia orang tua, dan jenis kelamin orang tua yang berperan.

Kelompok faktor yang memiliki nilai tertinggi kedua adalah kelompok faktor 2 yang terdiri dari waktu terjadinya perjalanan ke sekolah, jarak perjalanan ke sekolah, waktu tempuh perjalanan ke sekolah, biaya perjalanan ke sekolah, tujuan perjalanan orang tua, waktu terjadinya perjalanan orang tua yang memiliki nilai sebesar 10,151\%.

Kelompok faktor 3 yang terdiri dari jenis kelamin teman sebaya, jumlah pekerja dalam keluarga, tujuan perjalanan teman sebaya, waktu terjadinya perjalanan 
Region, Vol. 14, No.1, Januari 2019: 13-36

teman sebaya dengan nilai sebesar 6,469\%. Kelompok faktor 4 yang terdiri dari tujuan perjalanan ke sekolah, kenyamanan moda, efisiensi waktu ke sekolah, jalan bebas lalu lintas menerus, pemisahan jalur pejalan kaki dan kendaraan bermotor, keamanan anak menyeberang jalan dengan nilai sebesar 5,058\%. Kelompok faktor 6 yang terdiri dari kepemilikan moda orang tua, kepemilikan lisensi mengemudi orang tua dengan nilai sebesar $4,177 \%$.

\section{REFERENSI}

Alfajar, L. H. 2014. Upaya Pengembangan Karakter di Sekolah Negeri Sosrowijayan. Jurnal Universitas Negeri Yogyakarta.

Amirullah. 2002. Perilaku Konsumen, Edisi Pertama Cetakan Pertama. Yogyakarta: Graha Ilmu.

Arikunto, S. 2002. Metodologi Penelitian. Jakarta: PT. Rineka Cipta.

Arikunto, S. 2006. Prosedur Penelitian Suatu Pendekatan Praktik, Ed Revisi VI. Jakarta: PT. Rineka Cipta.

Arroba, T. 1998. Decision Making by Chinese-US. Journal of Social Psychology, 102116.

Basrowi, \& Suwandi. 2008. Memahami Penelitian Kualitatif. Jakarta: Rineka Cipta.

Black, J. A. 1995. Urban Mass Transportation Planning. Singapore: Mc Graw Hill Inc.

Bruton. 1975. Model Transportasi. Jakarta: Erlangga.

Daely, K., Sinulingga, U., \& Manurung, A. 2013. Analisis Statistik Faktor-faktor yang Mempengaruhi Indeks Prestasi Mahasiswa. Saintia Matematika, 483-494.

Delaune, S., \& Ladner, P. K. 2002. Fundamentals of Nursing: Standards \& Practice, Second Edition. New York: Delmar.

Djakfar, L., Amelia, K. I., \& Akhmad, S. N. 2010. Studi Karakteristik dan Model Pemilihan Moda Angkutan Mahasiswa Menuju Kampus (Sepeda Motor atau Angkutan Umum) di Kota Malang. Jurnal Rekayasa Sipil Universitas Brawijaya Malang.

Djarwanto. 1994. Pokok-pokok Metode Riset dan Bimbingan Teknis Penulisan. Yogyakarta: Liberty.

Golany, Gideon. 1976. Social Planning. New Town Planning. Principles and practice. New York: John Wiley and Sons Inc.

Gonzaga, J., \& Villoria, O. 1999. An Analysis of Travel Activity. Journal of The Eastern Asia Society for Transportation Studies:Intelligent Transportation System and Demand.

Gunarsa, S. D. 1993. Psikologi untuk Keluarga. Jakarta: BPK Gunung Agung.

Gunarsa, S. D., \& Gunarsa, Y. S. 2006. Psikologi Perkembangan Anak dan. Jakarta: PT BPK Gunung Mulia.

Hair, J. F. 1988. Multivariate Data Analysis, 1st Edition. New York: Prentice Hall International, Inc.

Hasan, I. 2004. Pokok-pokok Materi Teori Pengambil Keputusan. Bogor: Ghalia Indonesia.

Hobbs, F. 1995. Traffic Planning and Engineering. (S. d. Waldjono, Penerj.) Yogyakarta: Gadjah Mada University Press.

Janti, S. 2014. Analisis Validitas dan Reliabilitas dengan Skala Likert Terhadap Pengembangan Si/Ti dalam Penentuan Pengambilan Keputusan Penerapan Strategic Planning pada Industri Garmen. Seminar Nasional Aplikasi Sains \& Teknologi (SNAST), (pp. Al55-160). Yogyakarta.

Jayakusumah, H. 2011. Analisis Faktor-faktor yang Mempengaruhi Konsumen dalam Keputusan Pembelian Teh Celup Sariwangi. 
Salsabila Imtiyas dkk, Faktor-faktor yang...

JF, E., Blackwell, R., \& W, M. P. 1994. Perilaku Konsumen. Jakarta: Bina Rupa.

Jonathan, S. 2006. Metode Penelitian Kuantitatif dan Kualitatif. Yogyakarta: Graha Ilmu.

Kardiyali, L. 1991. Traffic Engineering and Transport Planning. New Delhi: Khanna Publisher.

Keating, W. Dennis, Norman Krumholz. 2000. Neighborhood Planning. Journal of Planning Education and Research 20(1): p. 111 - 114

Kementerian Pemberdayaan Perempuan dan Perlindungan Anak. 2015. Bahan Advokasi Kebijakan KLA. Jakarta.

Khisty, C. J., \& B Kent, L. 1998. Transportation Engineering An Introduction. London: Prentice-Hall.

Kotler, P. 2003. Manajemen Pemasarana, Edisi Kesebelas Jilid Satu. Jakarta: PT Indeks.

Kurniasih, Diena. 2013. Analisis Moda Perjalanan Sekolah (Studi Kasus: SMP 5 Yogyakarta). Tesis. Universitas Gajah Mada Yogyakarta.

Miro, F. 2005. Perencanaan Transportasi untuk Mahasiswa, Perencana, dan Praktisi. Jakarta: Erlangga.

Moi, Fransiska. 2015. Faktor-faktor yang Mempengatuhi Pemilihan Moda Transportasi untuk Perjalanan Kuliah (Studi Kasus: Mahasiswa/i Universitas Atma Jaya Yogyakarta). Universitas Atma Jaya Yogyakarta.

Morlok, E. K. 1985. Pengantar Teknik dan Perencanaan Transportasi. (J. K. Hainim, Penerj.) Jakarta: Erlangga.

Muller, S., \& et, a. 2008. Travel-to-school Mode Choice Modelling and Patterns of School Choice in Urban Areas. Journal Dresden University of Technology.

Munandar, A. S. 2004. Psikologi Industri dan Organisasi. Jakarta: Universitas Indonesia Press.

Nawawi, H. 1993. Metode Penelitian Sosial. Yogyakarta: Gajah Mada University Press.

O'hagan, K. 2006. Identifying Emotional \& Psychological Abuse. New York: Open University Press, Mc Graw-Hill Education .

Ortuzar, J. d., \& Willumsen, L. G. 1994. Modelling Transport, Second Edition. Chicester: John Wiley \& Sons.

Papacostas, C., \& Prevedouros, P. 1993. Transportation Engineering and Planning, Second Edition. Englewood Cliff USA: Prentice-Hall.

Perry, C. 1929. The Neighbourhood Unit. Neighbourhood and Community Planning. Regional Survey of New York and Its Environs, VII, 21-140.

Phillips, J. 2002. Application of Statitics in Educational.

Putri, R. A. 2012. Studi Kesesuaian Prinsip-prinsip Fisik Konsep Neighbourhood Unit dalam Penerapan Pengembangan Perumahan Formal (Studi Kasus: Perumnas Bumi Rancaekek Kencana dan Bumi Serpong Damai). Tesis.

Rabindra, Ida Bagus. 2000. Pola Komunitas Tabanan Bali. Tesis. Jurusan Teknik Planologi ITB.

Rini, E. F., Putri, R. A., Mulyanto, \& Handayani, N. 2017. Ecological Impact of Primary Education Facilities Based on Child Friendly Neighbourhood Unit Criteria in Surakarta. Center of Information and Regional Development (PIPW) LPPM UNS.

Rohe,William and Speiregen. 1985. Planning with Neighborhood. The University Of North Carolina Press.

Rustomo, Oscar Bintang. 2014. Transportasi Mahasiswa Fakultas Teknik UNS untuk Mendukung Program Green Campus. Skripsi. Universitas Sebelas Maret Surakarta.

Santoso, S. 2004. Santoro 2004 . Jakarta: Gramedia.

Saxena, S. C. 1989. Introduction to Real Variable Theory. New Delhi: Prentice Hall of India.

Sugiyono. 2007. Metode Penelitian Kuantitatif Kualitatif dan R\&D. Bandung: Alfabeta.

Sugiyono. 2012. Metode Penelitian Kuantitatif Kualitatif dan R\&D. Bandung: Alfabeta. 
Region, Vol. 14, No.1, Januari 2019: 13-36

Sujarto, D. 1976. Pemekaran Kota atau Dekonsentrasi Planologis? Tinjauan Mengenai Hubungan Permukiman Desa-Kota. Majalah Prisma, hal. 40-50.

Supranto. 2003. Statistik Teori dan Aplikasi, Edisi Lima. Jakarta: Erlangga.

Supranto, J. 2003. Metode Riset Aplikasi Dalam Pemasaran. Edisi Revisi Ketujuh. Yogyakarta: Rineka Cipta.

Suryadi, K. 2002. Sistem Pendukung Keputusan. Bandung: PT Remaja Rosdakarya.

Suryanto. 1989.Model Neighborhood Unit Sebagai Pendudkung Proses Komunitas.Thesis, Bandung : Jurusan Teknik Planologi ITB.

Tamin, O. Z. 1997. Perencanaan \& Permodelan Transportasi, Edisi Kedua. Bandung: ITB.

Teknomo, K. 1999. Penggunaan Metode AHP dalam Menganalisa Faktor-faktor yang Mempengaruhi Pemilihan Moda ke Kampus. Jurnal Teknik Sipil Universitas Kristen Petra Surabaya, 1, 31-39.

The Convention Rights of The Childs, 1989

Ujianto, \& Abdurachman. 2004. Analisis Faktor-faktor yang Menimbulkan Kecenderungan Minat Beli Konsumen Sarung (Studi Perilaku Konsumen Sarung di Jawa Timur). Jurnal Manajemen \& Kewirausahaan Universitas Kristen Petra, 34-54.

UU RI No. 23 Tahun 2002 Tentang Perlindungan Anak

Warpani, S. 1990. Merencanakan Sistem Perangkutan. Bandung: ITB.

Wicaksana, D. K. 2015, Maret. Analisa Sensitivitas dan Karakteristik Masyarakat di Kota Palembang dalam Memilih Moda Transportasi dengan Metode Analytical Hierarchy Proceess (AHP). Jurnal Teknik Sipil Universitas Sriwijaya, 3, 775782.

Wiratmanto. 2014. Analisis Faktor dan Penerapannya dalam Mengidentifikasi Faktor-faktor yang Mempengaruhi Kepuasan Konsumen Terhadap Penjualan Media Pembelajaran.

Wong, D. L., Hockenberry, E. M., Wilson, D., Winklestein, M. L., \& Scwartz, P. 2001. Buku Ajar Keperawatan Pediatrik. (A. Sutarna, Penerj.) Jakarta: EGC. 